\title{
Coordination between monetary policy and fiscal policy for an inflation targeting emerging market ${ }^{\text {is }}$
}

\author{
Zelal Aktas ${ }^{\mathrm{a}}$, Neslihan Kaya ${ }^{\mathrm{a}}$, Ümit Özlale ${ }^{\mathrm{b}, *}$ \\ a The Central Bank of the Republic of Turkey, Research and Monetary Policy Department, Ankara, Turkey \\ ${ }^{\mathrm{b}}$ Bilkent University, Department of Economics, Bilkent 06800, Ankara, Turkey
}

JEL Classification:

C32

C63

E30

Keywords:

Monetary policy

Non-linear state space models

Extended Kalman filter

\section{A B S T R A C T}

Several studies including Blanchard (2004) and Favero and Giavazzi (2004) imply that in emerging market economies, a tight monetary policy within an inflation-targeting framework could actually increase the price level due to the lack of fiscal discipline and the associated high risk premium. We extend their arguments in two ways. First, we introduce a semi structural model with time-varying parameters, where the risk premium is 'unobserved' and it is derived within the system. Such an approach fits better with the volatile nature of emerging market economies by allowing us to track down the time-varying effects of macroeconomic dynamics on both the model-consistent risk premium and the other key variables. Second, we obtain impulse response functions and analyze the implications of a tight monetary policy on major macroeconomic variables. Taking the Turkish economy as our reference point, we find that the arguments of Blanchard (2004) and Favero and Giavazzi (2004) seem to be valid.

( 2009 Elsevier Ltd. All rights reserved.

\section{Introduction}

The recent works by Blanchard (2004) and Favero and Giavazzi (2004) clearly show the importance of fiscal discipline and debt dynamics on the performance of inflation targeting for emerging markets. In an environment, where the domestic public debt is high and the average maturity is short, concerns

\footnotetext{
约The authors would like to thank Refet Gürkaynak, Hakan Kara, Fethi Öğ̈̈nç for their useful suggestions. The usual disclaimer applies.

* Corresponding author. Tel.: +90 312 2901955; fax: +90 3122665140.

E-mail address: ozlale@bilkent.edu.tr (Ü. Özlale).
} 
about debt sustainability increase the risk premium significantly. Such a case poses a problem for monetary policy: a tighter policy associated with higher real interest rates would increase the debt service burden and could actually lead to capital outflows and eventually to a depreciation of the domestic currency by increasing the default risk. Then, given the high degree of exchange rate passthrough, which is another common characteristic of the emerging markets, the depreciation of the domestic currency increases the price level. As a result, the "price puzzle", which stems from the misidentification of VAR models in the literature, can actually emerge as a structural characteristic of emerging market economies, which implement tight monetary policies.

The argument above relies heavily on the operation of the uncovered interest rate parity condition in an unconventional way. Thus, developing an accurate measure of risk that reflects especially the fiscal performance of the economy emerges as a critical issue. In this context, the EMBI spread, prepared by JP Morgan has been used as the risk premium measure in many empirical studies. Intended principally for portfolio management purposes, this spread provides a measure of pure sovereign default risk and is constructed as excess promised returns on the United States Treasury.

However, it is still an open question whether the changes in the EMBI spreads are exclusively due to the fiscal performance of the economy. There are other factors as well which lead to significant movements in these spreads. Firstly, as Calvo (2003) argues, domestic factors appear to be irrelevant in explaining the EMBI spreads once the U.S. corporate spreads are taken into account. His study implies that the main determinant of this spread is "the risk appetite" of foreign investors. Secondly, EMBI spreads are highly sensitive to political news. Even in cases where political developments have temporary or negligible effects on the structure of the economy, sharp changes in the EMBI spreads are observed. Moreover, the bonds that form the EMBI spread typically have long maturities that do not reflect the government's fiscal flow position, which is another critical factor. Consequently, it can be argued that EMBI spreads reflect not only the fiscal side developments but also the external factors and the political news. Therefore, the changes in the EMBI spreads cannot be viewed as being derived solely from fiscal fundamentals. Finally, EMBI spreads are weighted averages that are not based on a structural model. However, as Ferrucci (2003) mentions, the default probability, thus the fiscal performance, depends on many macroeconomic factors such as the average maturity of the debt, risk-free interest rates, the country's leverage ratio and the expected future primary surpluses. Furthermore, there are several studies that analyze the interaction between fiscal policy and exchange rate policy. ${ }^{1}$ Consequently, it may provide insightful results if the risk premium associated mainly with the domestic factors could be derived from a structural model, which includes the above factors and is consistent with the overall characteristics of the economy.

In this paper, consistent with the above arguments, we treat the 'risk premium' as an unobserved variable and derive it from a system of equations with time-varying parameters. In that sense, we obtain a 'model consistent' risk premium from a system which is designed to reflect the characteristics of an inflation-targeting emerging market economy with fiscal problems. A time-varying parameter framework is preferred since it will better fit with the volatile macroeconomic environment and the frequent structural changes in these economies. Such a methodology also allows us to track down the time-varying effects of macroeconomic dynamics on both the risk premium and other related variables. We also generate the impulse response functions and analyze the implications of the monetary policy on the system as a whole.

As will be clarified later, another contribution of this paper lies in the estimation methodology. Since the 'unobserved' risk premium and the time-varying parameters need to be simultaneously estimated, the state space representation of the model will have a non-linear characteristic, where the standard Kalman Filter fails to be appropriate. Then, the Extended Kalman filter (EKF), which is designed for the estimation of such non-linear systems, is employed.

Finally, since the above-mentioned papers stress the importance of fiscal performance on the success of monetary policy, for the application, an emerging market that reflects such characteristics should be chosen. We believe that the Turkish economy stands out as a very good example: After the

\footnotetext{
${ }^{1}$ Among these, Reinhart (2002) states that approximately $85 \%$ of all the defaults in emerging countries were linked to currency crises, which is a finding that explains the close relationship between the exchange rate and fiscal performance.
} 
collapse of the exchange rate-based stabilization program in February of 2001, the Turkish economy witnessed its deepest financial crisis, along with a huge debt burden. After the detrimental effects of the crisis ended, the Central Bank started to implement a form of implicit inflation-targeting regime together with intense efforts to lower the debt burden. ${ }^{2}$ Thus, the Turkish economy seems to incorporate all the characteristics that are necessary to this study, such as a volatile macroeconomic environment with fiscal problems and a form of inflation-targeting framework.

The following section provides a brief overview of the Turkish economy for the 1999-2006 period with special emphasis on the debt structure. The structural model is described and the estimation procedure is introduced in the next section. Then, the estimation results and the impulse response functions are discussed. The final section concludes the paper.

\section{The Turkish economy: 1999-2006}

In the late 1990s, the incomplete financial and institutional infrastructure in Turkey discouraged foreign direct investment and necessitated the use of debt-related financial instruments to close the Turkish financing gap. In addition, a fragile banking system together with high real interest rate costs due to the increased domestic borrowing of the fiscal sector shaped the structure of the Turkish economy. The monetary policy, on the other hand, was mainly accommodating the fiscal side, as a means of stabilizing the financial gaps. ${ }^{3}$

Imbalances arising from public budget limitations, namely budget deficit and its financing method, put direct and, through expectations, indirect pressure on the economy, which accumulated through the end of the 1990s. Following the 1998 Russian crisis and the devastating 1999 earthquake, the Turkish economy had entered an unsustainable path by the end of $1999 .{ }^{4}$ This forced the policy makers to introduce a new policy framework. Hence, the "2000-2002 Program" was introduced to decrease inflation rate, alleviate the public burden and reduce the debt stock to a sustainable level. A program of structural reforms, including the privatization of public enterprises, also supported it.

Due to the reluctance to make structural reforms, the lack of supervision and regulation in the banking sector, the initial credibility gain, which concealed the accrued fragilities of the economy for a while, started to erode after the first half of the year. Though the first turmoil in November 2000 was successfully eased by Central Bank intervention in the money market, uncertainties aggravated the deterioration of expectations after November. The exchange rate-based stabilization experience of Turkey for over a year was abandoned following the severe crisis on 22 February 2001. The Central Bank was forced to quit the exchange rate peg and start to implement a floating exchange rate regime.

A new economic program for strengthening the Turkish economy was announced in May 2001. This program intended to make a structural transformation in the economy and therefore placed heavy emphasis on the implementation of the key structural reforms in public finance and the banking sector as well as on the implementation of prudent fiscal and monetary policies with a view to placing the Turkish economy on a sustainable growth path. To this end, the Central Bank announced at the beginning of 2002 that an inflation-targeting regime would be the final target of the monetary policy with the overriding objective of achieving and maintaining price stability. However, consistent with the fiscal theory of price level, both the high level of debt and its structure had been hindering the effectiveness of the monetary policy. The debt stock consisted mostly of short-term debt, which was indexed to inflation and financial assets. This structure, in turn, made debt stock management the center of attention and led to frequent arguments regarding debt sustainability. The fragile debt structure resulted in excess sensitivity to expectations of political uncertainty and therefore, diminished the effectiveness of economic policies.

\footnotetext{
2 The Central Bank of the Republic of Turkey has been implementing a formal Inflation-Targeting regime since January 2006.

3 See Celasun (2002).

${ }^{4}$ At the end of the year, the inflation rate was 68.8 percent, year-on-year, and the fiscal sector borrowing requirement, including duty losses, reached 28.9 percent, doubling the 1990-1999 average. The domestic debt stock to GDP ratio almost tripled the 1990-1999 average and increased to 42,6 percent.
} 
Hence, an interim period of implicit inflation targeting was adopted until debates on the sustainability of the public debt stock were no longer at the top of the economic agenda. ${ }^{5}$ In time, considerable progress was made in the transition to inflation-targeting regime: CPI inflation undershot the targets four years in a row and inflation expectations converged to the targets. Worries pertaining to the continuity of fiscal discipline eased considerably. Financial markets started to become deeper, and the financial sector became less fragile. Although there are significant signs of improvement, fiscal policy still continue to be a challenge. ${ }^{6}$ This statement is supported by the fact that real interest rates are still high and that the decline in debt reductions lost pace in spite of high economic growth rates, currency appreciation and fiscal discipline. Yllmaz (2007) argues that the continuation of reforms to increase the quality of fiscal adjustments - which are still to be materialized - are as crucial as the improved structure of the debt stock.

The message from the above discussion is clear. The debt structure and the fiscal stance constitute a clear obstacle for the monetary authority especially during the period under consideration. Moreover, a tight monetary policy could actually worsen this scenario by increasing the already high risk premium in the economy. In that sense, the Turkish economy stands out as a good example.

\section{The model}

In this section, we introduce our model and the estimation methodology. The model is based on the assumption that as long as there are concerns about debt sustainability, the uncovered interest parity condition can operate in an unconventional fashion: increases in interest rates as part of a tight monetary policy further increase the probability of default and lead to a higher risk premium required by the investors. As a result, capital outflows and currency depreciation are observed, which also worsen price dynamics, especially when there is a high degree of pass-through from exchange rate to prices.

For an empirical investigation of the above-mentioned scenario for the Turkish economy, we utilize a reduced form model that is consistent with the macroeconomic framework described in these papers. As can be seen below, this system of equations consists of time-varying parameters which reflect the volatile characteristics of an emerging market economy. Formally, the reduced form can be written as follows:

$$
\begin{aligned}
& R_{t+1}^{C B}=\alpha_{0, t} R_{t}^{C B}+\alpha_{1, t}\left(\pi_{t}-\pi_{t}^{*}\right)+\varepsilon_{t+1}^{C B} \\
& R_{t+1}^{T R}=\beta_{0, t} R_{t}^{T R}+\beta_{1, t} R_{t}^{C B}+\varepsilon_{t+1}^{T R} \\
& T D_{t+1}=(1+i) T D_{t}^{T L}+\left(1+i^{*}\right) e T D_{t}^{E X}-p s_{t}-p r i v_{t} \\
& D_{t+1}=\gamma_{0, t} D_{t}+\gamma_{1, t} R_{t}^{T R}+\gamma_{2, t} D E P R_{t}+\varepsilon_{t+1}^{D} \\
& D E P R_{t+1}=\varphi_{0, t} P_{t}+\varphi_{1, t}\left(R_{t}^{T R}-R_{t}^{U S}\right)+\varepsilon_{t+1}^{E R}
\end{aligned}
$$

\footnotetext{
5 The Central Bank had started to implement implicit inflation targeting as the monetary policy framework by the beginning of 2002. Overnight interest rates were chosen as the policy instrument in a forward-looking manner to achieve the inflation targets jointly set by the Government. This policy was supported by a floating exchange rate regime, fiscal discipline and ongoing structural arrangements (see CBRT press release at http://www.tcmb.gov.tr/yeni/announce/2005/ANO2005-45.pdf).

${ }^{6}$ For empirical evidence, see Emir et al. (2007).
} 


$$
\pi_{t+1}=\theta_{0, t} \pi_{t}+\theta_{1, t} D E P R_{t}+\theta_{2, t} y_{t}+\varepsilon_{t+1}^{\pi}
$$

$$
y_{t+1}=\partial_{0, t} y_{t}+\partial_{1, t} R E R_{t}+\partial_{2, t} R_{t}+\varepsilon_{t+1}^{y}
$$

$$
N A_{t+1}=R_{t+1}^{F A}\left(N A_{t}+N X_{t}\right)
$$

$$
C A_{t+1}=\mu_{0, t} C A_{t}+\mu_{1, t} R E R_{t}+\mu_{2, t} y_{t}+\varepsilon_{t+1}^{C A}
$$

$$
\operatorname{Pr}_{t+1}=\phi_{0, t} D_{t}+\phi_{1, t} M A T_{t}+\phi_{2, t} C A_{t}+\phi_{3, t} P S_{t}+\phi_{4, t} \operatorname{Pr}_{t}+\phi_{5, t} E M B I^{+}+\varepsilon_{t+1}^{P r}
$$

where $\pi_{t}$ is the monthly, CPI-based annualized inflation, $\pi^{*} t$ is the targeted rate of inflation, $\mathrm{DEPR}_{\mathrm{t}}$ is the annualized depreciation rate of the domestic currency (TL/USD), $R^{T R}$ is the treasury bill secondary market rate, $\mathrm{R}^{\mathrm{US}}{ }_{t}$ is the U.S. federal funds rate, $\mathrm{R}^{\mathrm{CB}}{ }_{t}$ is the central bank overnight target rate, $\mathrm{TD}_{t}$ is the total accumulated debt stock, $\mathrm{eTD}^{\mathrm{Fx}}{ }_{\mathrm{t}}$ is the total accumulated foreign debt stock in terms of domestic currency, $\mathrm{i}$ is the interest rate on domestic debt, $\mathrm{i}^{*}$ is the interest rate on foreign debt, $\mathrm{ps}_{\mathrm{t}}$ is the primary surplus level, priv $_{t}$ is the privatization income, $D_{t}$ is the total consolidated debt stock ratio to GDP, $y_{t}$ is the output gap, $R_{t}$ is the real interest rate, $R E R_{t}$ is the percentage change in the real exchange rate, $N A_{t}$ is the net foreign position of the economy, $\mathrm{R}_{t+1}^{\mathrm{FA}}$ is the total return on the net foreign asset portfolio, $\mathrm{NX}$ is the net exports, $\operatorname{Pr}_{t}$ is the unobserved risk premium, $\mathrm{MAT}_{t}$ is the average maturity of domestic borrowing, $\mathrm{CA}_{\mathrm{t}}$ is the current account deficit ratio to GDP, $\mathrm{PS}_{\mathrm{t}}$ is the primary surplus ratio to GDP and $\mathrm{EMBI}^{+}$is the JP Morgan EMBI spread.

The first equation is a standard, Taylor rule type, policy rate equation that depicts the relationship between the central bank policy rate and the rate of inflation. The CBRT reacts to a change in the inflation by changing its policy rate. In order to avoid a possible autocorrelation and to capture the "interest rate smoothing" incentive, the lagged value of the overnight rate is also added. The sign of the coefficient for inflation is not unambiguous; it is possible that an increase in interest rates will lead to higher inflation.

The second equation shows a very simple relationship between the secondary market Treasury bill rate and the Central Bank policy rate, indicating that any movement in the policy rate of the Central Bank would have an impact on longer-term rates.

The third equation is a standard debt accumulation identity, where the primary surplus as an indicator of the fiscal discipline and privatization income are also taken into account.

The fourth equation states that the debt to GDP ratio of the economy depends on its own lag, the Treasury bill rate and the depreciation rate. While an increase in the Treasury bill rate raises the current period's cost of debt financing, the depreciation of the currency increases the debt burden of the foreign exchange denominated debt. As a result, these two factors should affect the debt stock to GDP ratio negatively.

Although both the third and the fourth equations characterize the debt dynamics, they have different implications. For the Turkish economy, thanks to the periods of high economic growth rates, while we may observe no significant change in the total debt stock, the debt to GDP ratio may decrease considerably. In fact, Fig. 1 states that, for the period under consideration, the total debt stock and the total debt to GDP ratio follow significantly different paths. In that case, analyzing the debt dynamics by focusing solely on the total debt accumulation may be misleading since the risk premium or the concerns about debt default may be reduced due to a decrease in the debt to GDP ratio. In addition, for the Turkish economy, there have been unexpected factors (fiscal skeletons) that add to the debt stock such as the cost of the banking sector bailouts that took place right after the February 2001 crisis. These unforeseen developments can be captured by imposing a disturbance term as in the fourth equation. 


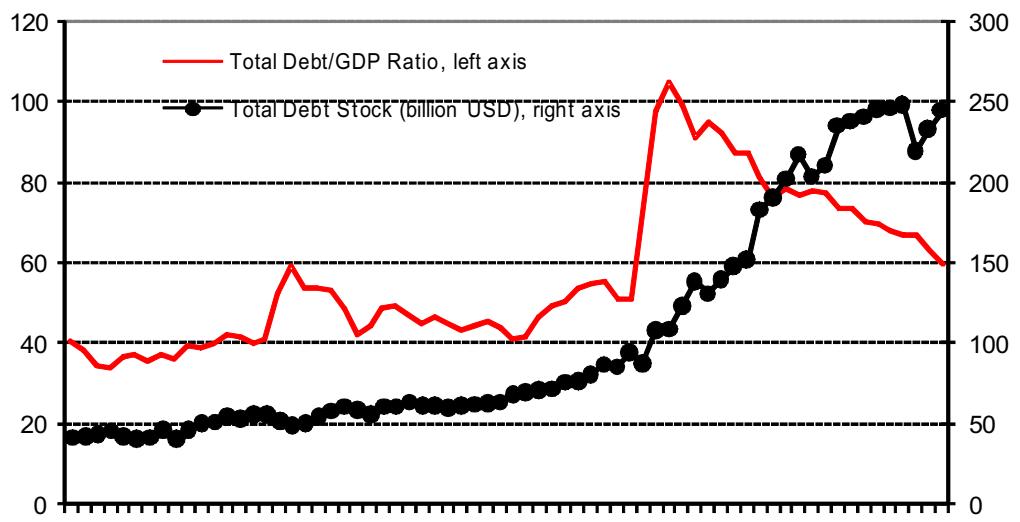

Source: Undersecretariat of Treasury of Republic of Turkey and Turkish Statistical Institute.

Fig. 1. Debt /GDP versus level of debt stock. Source: Undersecretariat of Treasury of Republic of Turkey and Turkish Statistical Institute.

In the fifth equation, the depreciation rate is expressed as a combination of the risk premium and the interest rate differential. Consistent with the conventional uncovered interest rate parity condition, an increase in the interest rate differential causes an appreciation and vice versa. However, if there is an increase in the perceived risk, then through capital outflows, the currency may depreciate. As a result, the overall effect on the exchange rate depends on whether the risk premium channel or the uncovered interest rate parity condition dominates.

The sixth equation is a multivariate inflation specification, where inflation's own lag is used to include inertia and the depreciation rate reflects the pass-through. The output gap measure is taken from Kara et al. (2007a) to reflect the excess demand pressure on the inflation.

The seventh equation specifies the above-mentioned output gap as a function of its lagged value, the real exchange rate and the real interest rate. ${ }^{7}$ The relationship between the output gap and the real exchange rate is discussed in Kara et al. (2007a). Here, it is more important to note that the monetary policy affects the inflation through the impact of the real interest rates on the aggregate demand, as proposed in Rudebusch and Svensson $(1998,1999)$.

The eighth equation, adopted from Gourinchas and Rey (2005), represents the accumulation identity for net foreign assets in the economy. It basically states that the net foreign position $\left(\mathrm{NA}_{\mathrm{t}}\right)$ increases with net exports $\left(\mathrm{Nx}_{\mathrm{t}}\right)$ and with the total return on the net foreign asset portfolio $\mathrm{R}_{\mathrm{t}+1}^{\mathrm{FA}}$.

The ninth equation defines the current account balance to GDP ratio as a function of its lagged value, the real exchange rate and the output gap. Appreciation of the exchange rate and positive output gap are expected to generate a current account deficit.

The relationship between the current account balance and net foreign assets is straightforward. A current account deficit implies that citizens of a country increase their indebtedness to foreigners. However, similar to the discussion on the debt dynamics, an identity equation for the net foreign assets and an equation that displays the current account to GDP ratio dynamics may reveal different information regarding the economy. One reason for this is that the growth rate of the Turkish economy depends significantly on the exchange rate dynamics. Lowered costs of imported investment goods due to overvalued domestic currency often lead to an increase in the overall production. Thus, even if we observe a considerable change in the net foreign assets, the current account to GDP ratio, which is seen

\footnotetext{
${ }^{7}$ It may seem that given the dynamics of output in Eq. (7); Eq. (3) and (4) determine the dynamics of the same variable. However, it should carefully be noted that Eq. (7) describes output gap, not the output growth. The output gap measure is taken from Kara et al. (2007a) which employs a structural time-series model and incorporates expert judgment to a great extent in order to reflect the dynamics of the Turkish economy. This series mainly reflects the business cycles of the economy but it does not co-move with the output growth series. Indeed, the correlation between the two series is found to be 0.16.
} 
as an important indicator of financial fragility, tends to move rather slowly. Therefore, net foreign assets and the current account deficit to GDP ratio contain different information. Moreover, these two variables may differ to a great extent taking into account the risk perception issue. The literature on the sustainability of current account deficits states that potential creditors may refrain from extending credit to countries with high current account to GDP ratios (possibly after a threshold that they have in mind) as those countries are perceived to be "bad risks". ${ }^{8}$ Furthermore, Errors and Omissions (EAO's) in balance of payments statistics may take on values as high as 3\% of the GDP from time to time, which is typically the case in Turkey, where the positive trend of EAO's during recent years attracts attention. ${ }^{9}$ As a result, for its distinct role in signaling a risk perception and due to high EAO's, we decided to add a current account to GDP ratio equation to the system.

The tenth equation is written down to identify the possible components of the unobserved risk premium. It is assumed that, other than its own lag, the risk premium is affected by the average maturity of domestic borrowing, the ratios of debt stock, the current account deficit and the primary surplus to the GDP. The debt to GDP ratio is constructed using the consolidated debt stock, both foreign and domestic. The average maturity is included to capture the risk perception of the people lending to the Treasury to finance its deficit. It is also a very important indicator of the fiscal flow position. Due to the fact that foreign investors view current account deficits as important signals of currency crisis, this variable is also added in the regressor matrix. Reinhart (2002) reports a very close link between currency crisis and defaults for the emerging markets, which provides support for such a specification. The primary surplus variable is used to reflect the fiscal discipline criteria. This variable also incorporates extra information as a measure of the credibility, especially in the presence of IMF stand-by agreements. ${ }^{10}$ Lastly, other than the effects of domestic factors on the unobserved risk premium, there is strong evidence that the risk premiums for different countries tend to co-move. Therefore, to account for international factors, we have also added EMBI+ spread, which shows the default risk for all emerging markets as a whole.

Finally, there are two points worth mentioning. Firstly, it should be reminded that all of the parameters in the model are assumed to be time varying, which reflects the characteristics of a volatile macroeconomic environment. By observing the time path of the coefficients and the impulse response functions, one can detect whether the arguments of Blanchard (2004) and Favero and Giavazzi (2004) are valid for the Turkish economy. Secondly, we have chosen to employ a backward-looking setup since the procedure to estimate such systems requires a recursive algorithm. In addition, to utilize a forwardlooking model and incorporate a term premium to the term structure, we should have the data that represents the expectations for the whole sample period. However, we have such information for only a minor fraction of the sample period, which leads us to use a backward-looking specification throughout the model. The next section provides the estimation procedure for the above-mentioned model.

\subsection{Estimation procedure}

This part introduces the state space representation of the model and the non-linearity, which necessitates the employment of the extended Kalman filter. As the state space representation of the model shows, the state equation is time dependent due to the time-varying parameters to be estimated. Therefore, our state space model, which consists of the state equation and the observation equation, will be:

$$
x_{t+1}=\Phi_{t}\left(x_{t}\right)+\psi_{t}\left(z_{t}\right)+G_{t}\left(\omega_{t}\right)
$$

\footnotetext{
8 See Obsfeld and Rogoff (1997).

9 See Çıplak (2006).

${ }^{10}$ It may well be argued that when the primary surplus is constantly adjusted to remove any negative effects, the mechanism defined above might not hold. However, the Turkish experience, which is similar to the experiences of other emerging market economies, shows that the primary surplus target is rarely achieved to sustain a fiscal balance.
} 


$$
y_{t}=H_{t}\left(x_{t}\right)+\eta_{t}
$$

The above form is an example for a non-linear state space model, where $\Phi_{t}, \psi_{t}$ and $H_{t}$ are vectorvalued functions, $\omega_{t}$ and $\eta_{t}$ are uncorrelated zero-mean white noise sequences with covariance matrix $\mathrm{Q}_{t}$ are $R_{t}$, respectively. Note that both the time-varying parameter vector $\Phi_{t}$ and the state vector $x_{t}$ are presented in multiplicative form. Since these two vectors are to be estimated simultaneously, the state equation will have a non-linear feature, where the extended Kalman filter should be used.

\subsection{Applying EKF}

Note that $\Omega_{t}=\left[\begin{array}{l}\alpha_{0, t}, \alpha_{1, t}, \beta_{o, t}, \beta_{1, t}, \gamma_{0, t}, \gamma_{1, t}, \gamma_{2, t}, \varphi_{0, t}, \varphi_{1, t}, \theta_{0, t}, \theta_{1, t}, \theta_{2, t}, \\ \partial_{0, t}, \partial_{1, t}, \partial_{2, t}, \mu_{0, t}, \mu_{1, t}, \mu_{2, t}, \phi_{0, t}, \phi_{1, t}, \phi_{2, t}, \phi_{3, t}, \phi_{4, t}, \phi_{5, t}\end{array}\right]$ the parameter vector to be estimated.

It is convenient to assume that these time-varying parameters follow a random walk:

$$
\Omega_{t+1}=\Omega_{t}+\varsigma_{t}
$$

where $\zeta_{t}$ is any zero-mean white noise sequence uncorrelated with $v_{t}$ and with pre-assigned positive definite variances $\operatorname{Var}\left(\zeta_{\mathrm{t}}\right)=\mathrm{S}_{\mathrm{t}}$. If we treat the above equations as the new state vector and combine them, we will have the non-linear state space model:

$$
\begin{aligned}
& {\left[\begin{array}{l}
x_{t+1} \\
\Omega_{t+1}
\end{array}\right]=\left[\begin{array}{l}
\Phi_{t}\left(\Omega_{t}\right) x_{t} \\
\Omega_{t}
\end{array}\right]+\left[\begin{array}{l}
\psi_{t}\left(\Omega_{t}\right) z_{t}+G_{t}\left(\Omega_{t}\right) \omega_{t} \\
\varsigma_{t}
\end{array}\right]} \\
& y_{t}=\left[H_{t}\left(\Omega_{t}\right) 0\right]\left[\begin{array}{l}
x_{t} \\
\Omega_{t}
\end{array}\right]+\eta_{t}
\end{aligned}
$$

The non-linearity can also be seen in Eq. (14). Then, the EKF procedure can be applied to estimate the state vector, which contains $\Omega_{\mathrm{t}}$ as one of its components. That is, $\Omega_{\mathrm{t}}$ is estimated optimally. This procedure is called adaptive system identification, as noted in Anderson and Moore (1979). Both the extended Kalman filter algorithm and its application in non-linear state space models are discussed in Chui and Chen (1991) and Chen (1993).

\section{Results}

After the extended Kalman filter is executed, the 'model consistent' risk premium and the timevarying parameter estimates are obtained. In this section, we first analyze the risk premium series by giving references to the developments in the Turkish economy for the period under consideration. Next, the estimated time-varying parameters are discussed. Finally, the impulse response results are displayed.

\subsection{Risk premium}

Fig. 2 presents the derived risk premium series. It can be seen that right after the exchange ratebased stabilization program in the late 1999 , which was put into effect mainly to overcome the problems of debt sustainability and persistent inflation, the risk premium series seems to decline. However, the optimism at the beginning of the exchange rate-based stabilization program was replaced by the realization that the program would fail to achieve its goals of sustainable debt and low inflation. Thus, with the collapse of the program, we observe a sharp increase, which reaches a peak during the third quarter of 2001. The reason why the estimated risk premium is at its maximum two quarters after the February 2001 crisis is the high cost of the banking sector bailouts. At that time, the Treasury undertook the risk of the fragile banking sector by means of swap operations, which led to a sharp increase in the debt stock. Since our risk premium reflects the default risk, such a shock to the debt stock led to a further increase in the estimated risk premium. However, these concerns were partly eliminated and the first half of 2002 witnessed a dramatic improvement. Although no significant 


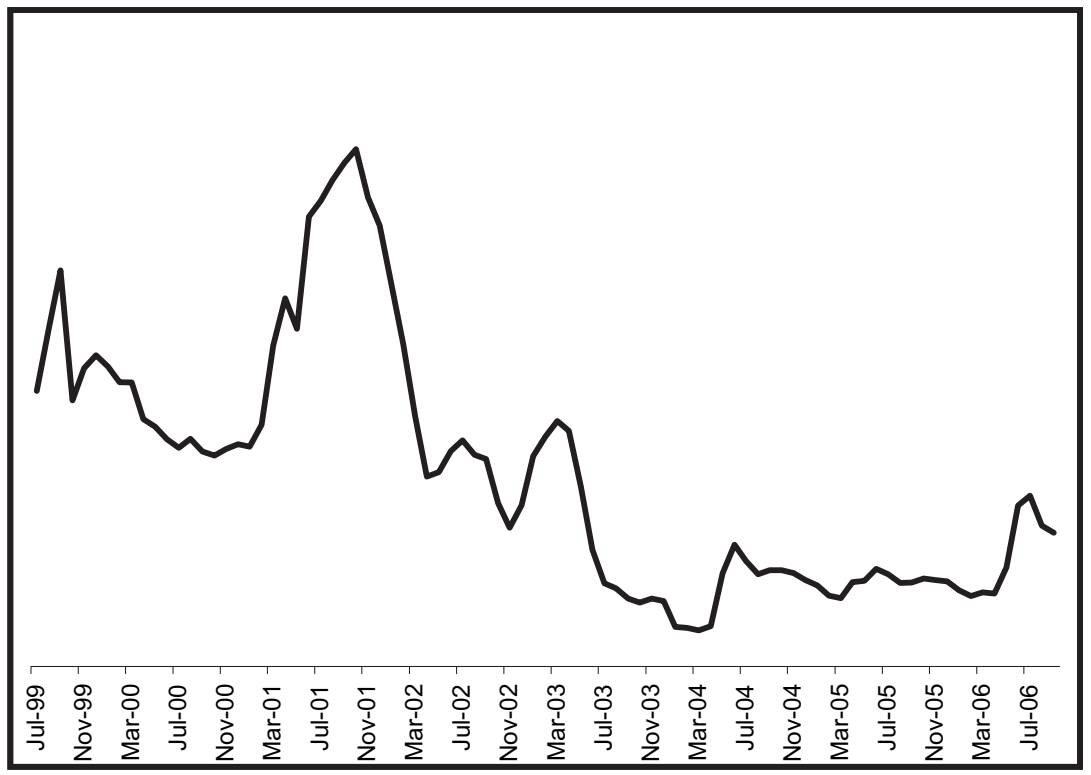

Fig. 2. The estimated risk premium.

change is observed in late 2002, the risk premium series again seems to pick up slightly from the beginning of 2003, reaching a local peak with the Iraq war. Then, we observe another sharp decline, which continued until February 2004, when the estimated series take its minimum value throughout the sample period. Both the positive external conditions and the improving fiscal discipline played important roles in this sharp decrease. Starting with the tight monetary policy era of the Federal Reserve, we detect an increase in the estimated series, which resulted in another local peak in June of 2004. Finally, until the global financial turbulence in May-June 2006, the estimated series remain steady.

\subsection{Time-varying parameter estimates}

Before interpreting the time-varying parameter estimates, it is necessary to display the estimation accuracy of the state vector. Although in reality the variables in the state vector are observed, the recursive algorithm treats these variables as unobserved and produces time-series estimates. As can be seen in Fig. 3, the estimated state variables are very close to their actual values, which indicate the accuracy of the estimation procedure.

As stated previously, one of the main advantages of setting the problem in an extended Kalman filter framework is obtaining time-varying parameter estimates. Since there are too many parameters to be interpreted, we will focus only on the key ones. In this context, the parameters in the uncovered interest rate parity, the risk premium equation, and the pass-through parameter in the inflation equation are analyzed. ${ }^{11}$ The plots of these time-varying parameters for the January 2000-September 2006 period are given in Fig. 4.

Before analyzing the parameters in the uncovered interest rate parity equation, it is worth mentioning again that the link between the exchange rate and the interest rate is not straightforward, especially for the emerging markets. As stated in Bergin (2006), the literature on New Open Economy Macroeconomics identifies these deviations from uncovered interest rate parity and argues that

\footnotetext{
11 The other estimated parameters are available upon request.
} 







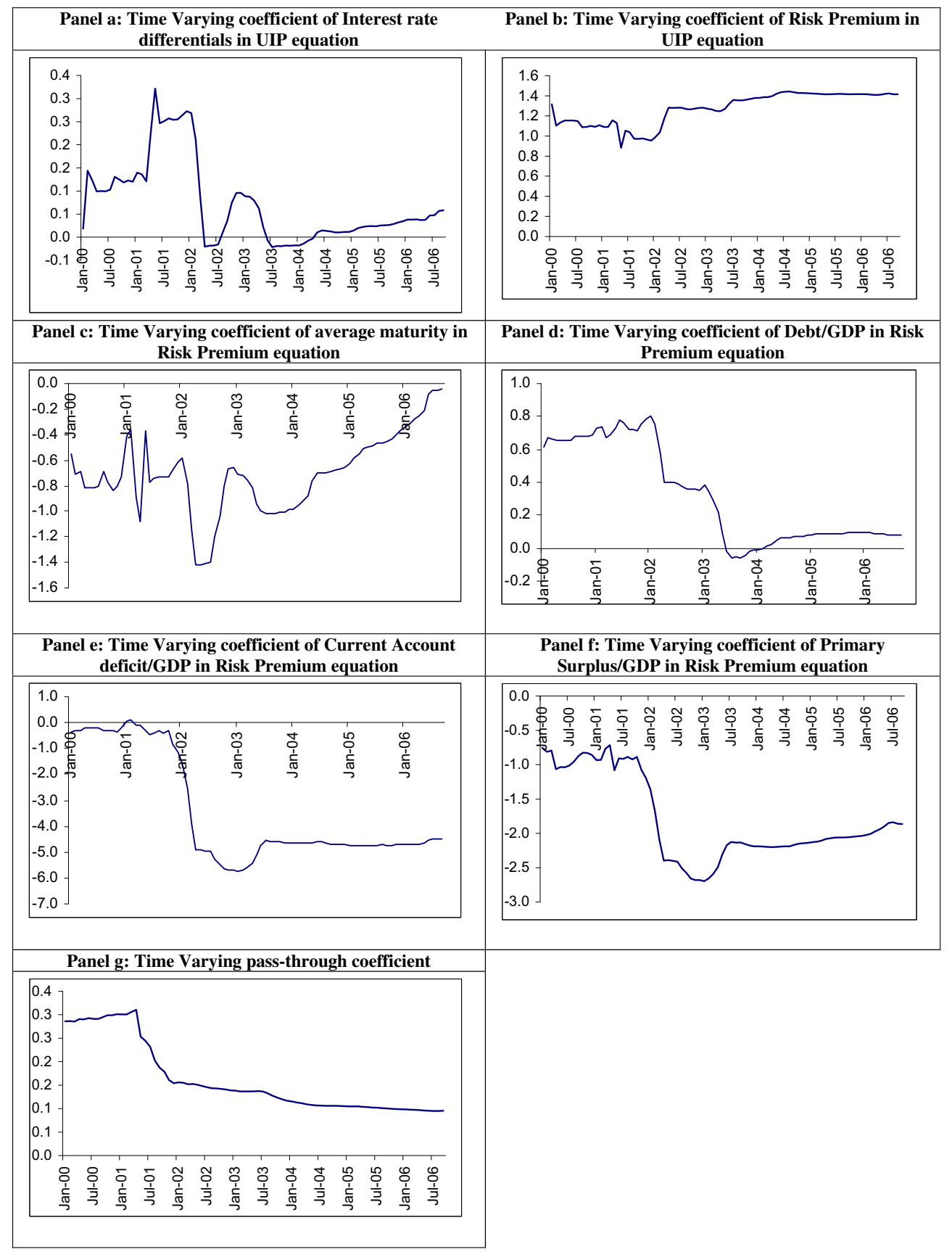

Fig. 4. Time-varying coefficients.

monetary policy actions fail to explain them. Therefore, our specification can also be viewed as an attempt to incorporate fiscal fundamentals into the uncovered interest rate parity condition. When the time paths of the parameters are observed, we see that the effect of the interest rate on the exchange rate changes significantly throughout the sample period, which provides support for our choice of 
a time-varying parameter framework. Panel (a) in Fig. 4 implies that, starting from March 2001, when the exchange rate was allowed to float freely, the unexpected positive relation between the interest rates and the depreciation rate of the domestic currency decreases sharply until August 2002. Next, we observe again a positive relationship between August 2002 and June 2003. This is the same exact time span when the estimated risk premium reaches a local peak. Then, the expected negative link between these two variables can be seen between June 2003 and May 2004, when the estimated risk premium series has a sharp decline and reaches a minimum as a result of the improved fiscal discipline. These findings are instructive. While concerns about the risk premium are high, an increase in the interest rate leads to a depreciation of the domestic currency. As long as the risk premium that reflects the fiscal side fundamentals decreases, the unexpected positive link between the interest rate and the exchange rate disappears. Combining this finding with the significantly positive effect of the risk premium on the uncovered interest rate parity condition, as shown in Panel (b) of Fig. 4, we might conclude that for the operation of the uncovered interest rate parity condition in the expected direction, concerns about fiscal sustainability should be lowered to a significant extent.

We can see from panel (d) of Fig. 4 that the coefficient of the debt to GDP ratio in the risk premium equation is positive and increases slightly with the growing concerns about debt sustainability. However, we see a sharp decline beginning with February 2002, when the expectations about the fiscal discipline improved. The end-sample estimate implies that, although still positive, the impact of the debt to GDP ratio on the risk premium decreased considerably during the sample period. In addition, panel (c) of Fig. 4 shows a negative relationship between the average maturity and the risk premium throughout the sample period. When the fiscal performance improves as we move towards the end of the sample period, the impact of the average maturity on the estimated risk premium decreases significantly. These two findings clearly show the importance of fiscal discipline on the estimated risk premium.

We also see in panels (e) and (f) that while the current account deficit increases the risk, the generated primary surplus as a requirement of the agreement with IMF seems to have a positive impact. It is also important to note that there seems to be a break for these estimated time-varying parameters after February 2002, when the fiscal performance started to improve.

Finally, the estimates for the pass-through coefficient in the inflation specification need to be interpreted. As panel (g) of Fig. 4 shows, a sharp decline in the pass-through coefficient is observed right after the end of the exchange rate-based stabilization program. More interestingly, it supports the view that the degree of pass-through declined with the improvement in the inflation in the post-crisis period. Such a finding suggests that the "indexation" behavior of the agents, which relates the changes in the exchange rate to the expectations regarding the price level, significantly decreased. These results are consistent with Kara et al. (2007b), who find that, with the implementation of the inflation-targeting framework instead of the fixed exchange rate regime, the exchange rate pass-through decreases considerably.

There are important conclusions to be drawn from these estimated time-varying parameters. First, the parameters significantly vary over time, which validates our methodology. Second, the changes in the risk premium emerge as a possible explanation of the deviations in the uncovered interest rate parity condition. Finally, the parameter estimates seem to be consistent with the scenario that Blanchard (2004) and Favero and Giavazzi (2004) imply for emerging markets. However, to have a clearer picture, an impulse response analysis is needed.

\subsection{Impulse response analysis}

The general framework in this study implies that, the results of a tight monetary policy may differ significantly, depending on the fiscal stance of the economy. Thus, to test the validity of this hypothesis, we chose two different periods: a tight monetary policy period with fiscal discipline and a tight monetary policy without fiscal discipline. July 2001 was chosen as the period when the economy was very fragile and there were serious concerns regarding the sustainability of debt. In contrast, September 2003 is chosen as the period when the effects of the financial crisis were alleviated and there were fewer concerns about the debt sustainability. Next, we obtained the impulse responses of a one percentage point increase in the Central Bank rate. The time-variation in the estimated 

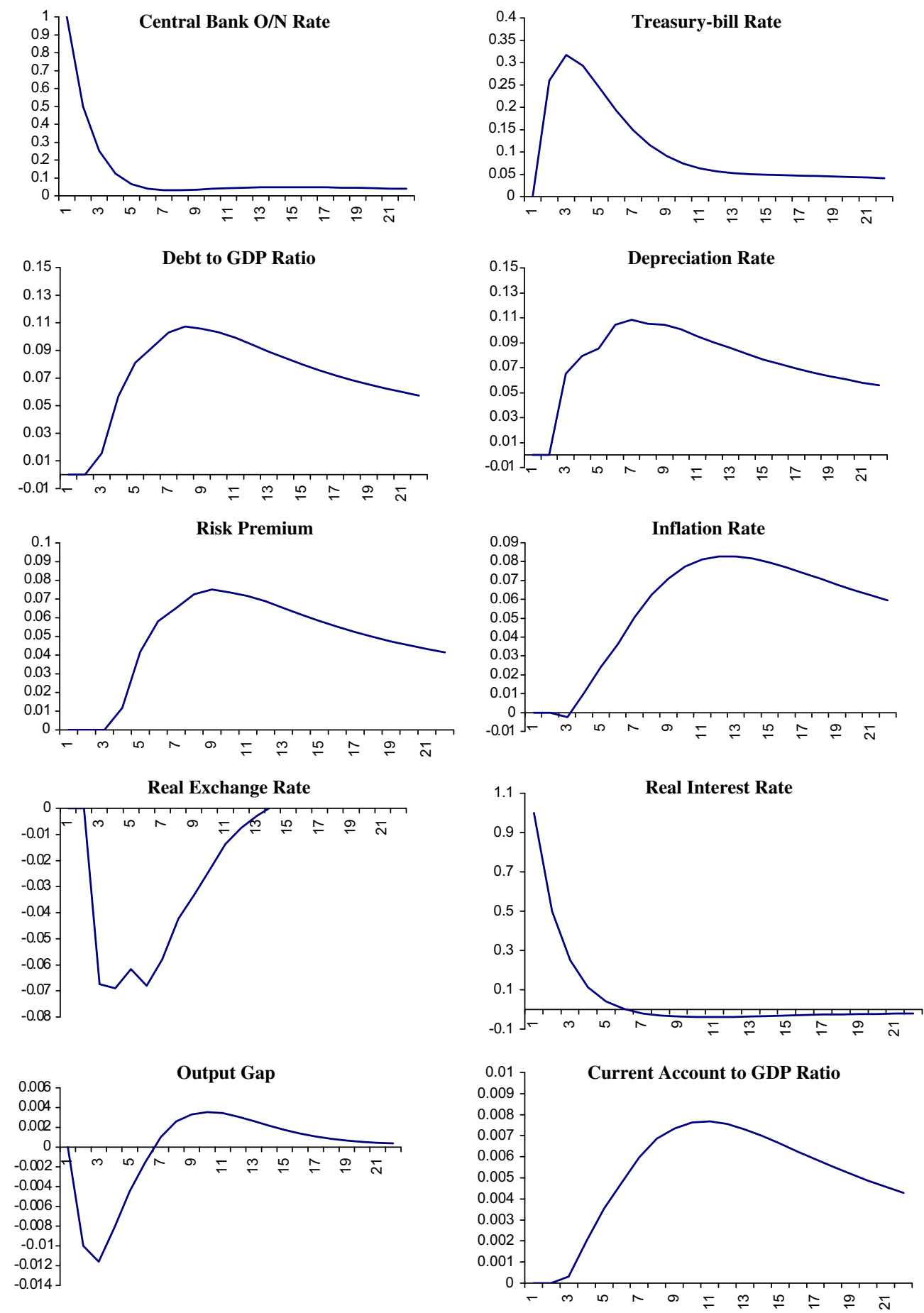

Fig. 5a. Central Bank Rate increases by 1 percentage point in July 2001. 

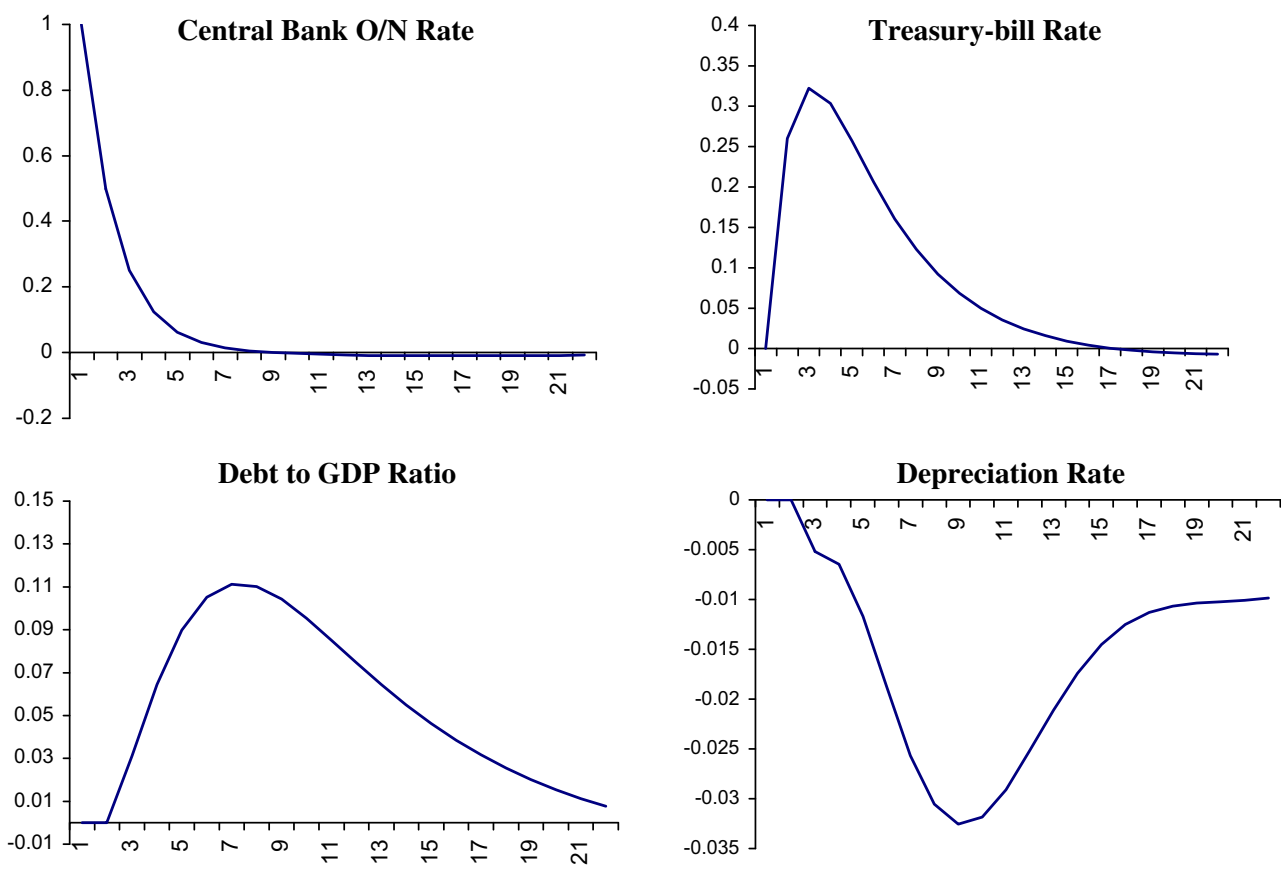

Risk Premium
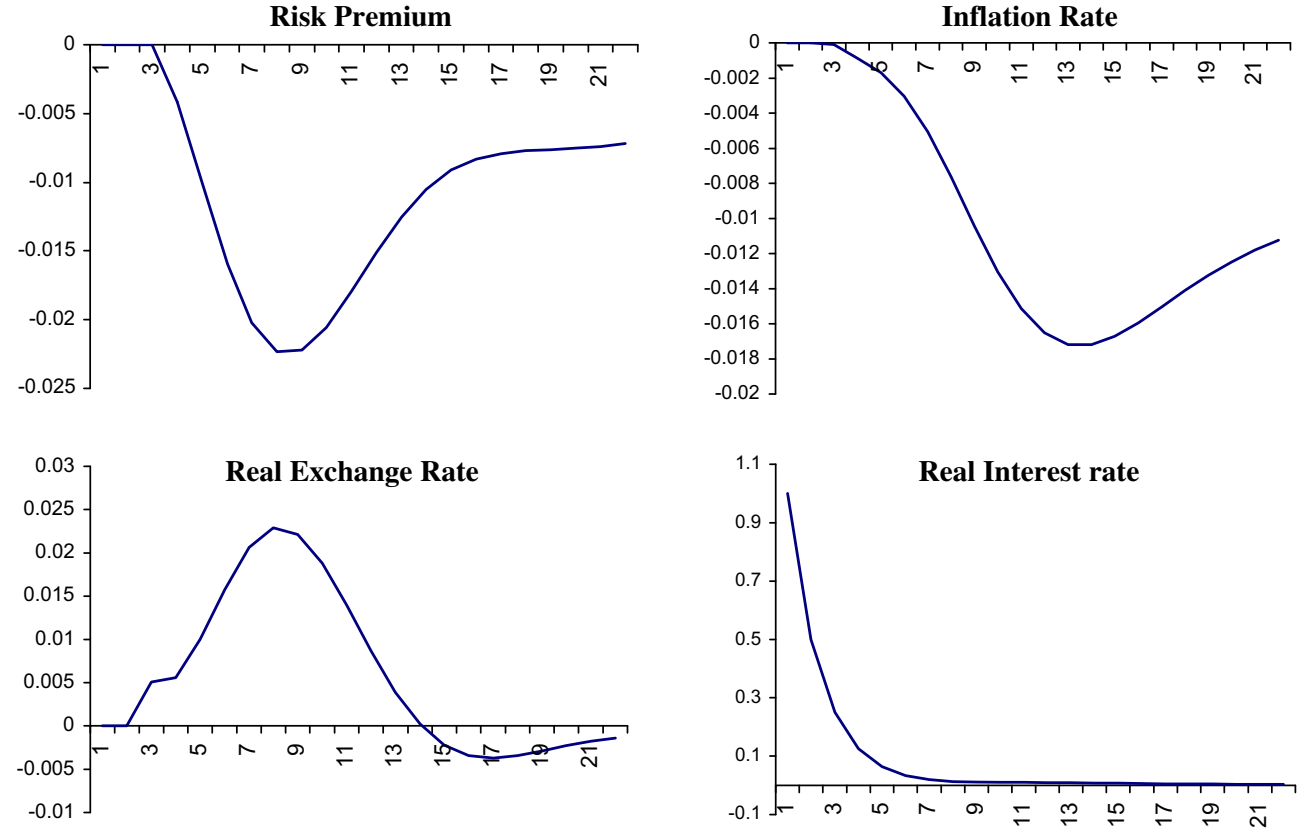

Fig. 5b. Central Bank Rate increases by 1 percentage point in September 2003. 
parameters was exploited to pin down the alternative scenarios of interaction between the monetary and fiscal policy regimes.

The impulse responses of a one percentage point increase in the Central Bank rate in July 2001 are presented in Fig. 5a. As can be seen, an increase in the monetary policy rate raises the cost of debt service, and the debt level rises. Therefore, triggered by an additional increase in the level of the debt stock, an increase in the risk premium is observed. The increase in the risk premium adds to the initial increase in debt, especially since it is accompanied by a depreciation in the exchange rate, which raises the value of foreign-currency denominated bonds in terms of the domestic GDP. The depreciation of the exchange rate also affects inflation expectations and, eventually, the inflation itself. This induces the Central Bank to increase the policy rate further, which further raises the cost of debt service; leaving the economy in a bad equilibrium.

Fig. $5 \mathrm{~b}$ represents the propagation of the same monetary policy action in September 2003, which is characterized by a more stable fiscal performance of the economy. As in the previous case, an increase in the overnight rate leads to an increase in the Treasury bill rate which increases the debt stock. However, this increase in the debt stock does not raise issues about its sustainability and affects the risk premium to a limited extent. In this case, the uncovered interest parity operates in a conventional way. That is, an increase in the interest rates leads to an appreciation of the domestic currency, which eventually leads to a decline in the inflation rate. Therefore, in an environment where fiscal discipline is partially achieved, a monetary policy action is not hindered by the fiscal performance of the economy and inflation can indeed be fought by implementing a tight monetary policy.

\section{Conclusion}

Several studies including Blanchard (2004) and Favero and Giavazzi (2004) clearly show the role of debt dynamics on the performance of inflation targeting. These studies imply that the presence of a 'risk premium' channel could actually cause the price level to increase when the central bank follows a tight monetary policy.

In this study, we extend their arguments in two ways. First, we derive a 'model consistent' risk premium from a system of equations with time-varying parameters. Such an approach both reflects the volatile nature of emerging market economies and allows us to track down the time-varying effects of macroeconomic dynamics on the risk premium. Second, we obtain impulse responses and analyze the implications of fiscal discipline on monetary policy.

We take the Turkish economy as our laboratory for this study. The results indicate that the estimated risk premium series is consistent with the path that the Turkish economy followed for the sample period. More importantly, by analyzing the time-varying parameter estimates and the impulse response functions, we can see that fiscal dynamics plays a very important role in the effectiveness of the monetary policy. These results also imply that as long as there is an improvement in the fiscal discipline, the uncovered interest rate parity condition operates in the expected direction.

\section{References}

Anderson, B.D.O., Moore, J.B., 1979. Optimal Filtering. Prentice-Hall, Englewood Cliffs, NJ.

Bergin, P.R., 2006. How well can the new open economy macroeconomics explain the exchange rate and the current account? Journal of International Money and Finance 25 (5), 675-701.

Blanchard, O., 2004. Fiscal Dominance and Inflation Targeting: Lessons from Brazil NBER Working Paper no. 10389.

Calvo, G., 2003. Explaining sudden stop, growth collapse and bop crisis. IMF Staff Papers 50, 1-20 (special issue).

Celasun, M. 2002. 2001 Krizi, Öncesi ve Sonrasý: Makroekonomik ve Mali Bir Deðerlendirme. Unpublished Manuscript. Department of Economics, Bilkent University, Ankara.

Chen, G., 1993. Approximate Kalman Filtering. World Scientific, Singapore.

Chui, C.K., Chen, G., 1991. Kalman Filtering with Real-Time Applications. Springer. Berlin.

Çıplak, U., 2006. Ödemeler Dengesinde Net Hata ve Noksan Kalemi Üzerine Bir Değerlendirme. Active-Bankacıllk ve Finans Dergisi 47 (8), 24-32.

Emir, O.Y., Özatay, F., Şahinbeyoğlu, G., 2007. Effects of US interest rates and news on the daily interest rates of a highly indebted emerging economy: evidence from Turkey. Applied Economics 39 (3), 329-342.

Favero, C., Giavazzi, F., 2004. Inflation Targeting and Debt: Lessons from Brazil NBER Working Paper no. 10390.

Ferrucci, G., 2003. Empirical Determinants of Emerging Market Economies' Sovereign Bond Spreads Bank of England Working Paper no. 205.

Gourinchas, P.O., Rey, H., 2005. International Financial Adjustment NBER Working Paper no. 11155. 
Kara, H., Öğünç, F., Özlale, Ü., Sarıkaya, Ç., 2007a. Estimating the output gap in a changing economy. Southern Economic Journal 74 (1), 269-289.

Kara, H., Tuğer, H.K., Özlale, Ü., Tuğer, B., Yücel, M.E., 2007b. Exchange rate regimes and pass-through: evidence from the Turkish economy. Contemporary Economic Policy 25 (2), 206-225.

Obsfeld, M., Rogoff, K., 1997. Foundations of International Macroeconomics. MIT Press, Cambridge, MA.

Reinhart, C.M., 2002. Default, currency crises and sovereign credit ratings. World Bank Economic Review 16 (2), $151-170$.

Rudebusch, G.D., Svensson, L.E.O., 1998. Policy Rules for Inflation Targeting NBER Working Paper no. 6512.

Rudebusch, G.D., Svensson, L.E.O., 1999. Eurosystem Monetary Targeting: Lessons from U.S. Data NBER Working Paper no. 7179.

Yılmaz, E. 2007. Facing Risk; Fiscal Adjustment, Credibility and the Structure of Public Debt. Unpublished Working Paper. Central Bank of the Republic of Turkey, Ankara. 